\begin{tabular}{|c|c|c|c|}
\hline & $\begin{array}{l}\text { Escola Superior } \\
\text { de Gestáo } \\
\text { Teconologia } \\
\text { [ipsantaréém] }\end{array}$ & KU & $\begin{array}{l}\text { ISSN 2029-7564 (online) } \\
\text { SOCIALINĖS TECHNOLOGIJOS } \\
\text { SOCIAL TECHNOLOGIES } \\
2013,3(1) \text {, p. } 189-207\end{array}$ \\
\hline
\end{tabular}

\title{
KIBERNETINIO SAUGUMO TEISINIS REGULIAVIMAS: KIBERNETINIO SAUGUMO STRATEGIJOS
}

\author{
Darius Štitilis \\ Mykolo Romerio universitetas, Lietuva, stitilis@mruni.eu \\ doi:10.13165/ST-13-3-1-13
}

\section{Santrauka}

Tikslas - išanalizuoti kibernetinio saugumo teisini reguliavima (strategijas) ES ir šio teisinio reguliavimo kontekste ivertinti Lietuvos kibernetinio saugumo programa.

Metodologija - tyrimui atlikti taikyti keli skirtingi metodai: tirdamas ES teisine baze del kibernetinio saugumo (kiek tai susije su strategijomis), autorius pasitelke lyginamaji metodą. ES bei pasirinktu užsienio valstybiu kibernetinio saugumo teisinio reguliavimo nustatymui taikytas empirinis teisiniu dokumentu analizes metodas. Buvo tiriami ES, pasirinktu valstybiu ir Lietuvos dokumentai dèl kibernetinio saugumo strategijų. Šis metodas leidžia ištyrus oficialius dokumentus tiksliai nustatyti ir aprašyti atitinkamo santykio galiojanti teisini reguliavima. Naudodamas mokslinès literatūros šaltinius autoriaus taike dedukcijos metodą, leidžianti daryti pakankamai patikimas išvadas. Taip pat autorius pasitelke naujausia mokslinę literatūrą.

Rezultatai - tyrimas atskleide, jog Lietuvos kibernetinio saugumo strategija per daug abstrakti ir neužtikrina tu pagrindiniu tikslu bei uždaviniu, kurie akcentuojami ES strategijoje bei atskiru užsienio valstybiu kibernetinio saugumo strategijose. Be to, Lietuvoje trūksta pamatiniu teisès normu kibernetinio saugumo srityje. Prieš kelis metus buvo parengtas Lietuvos Respublikos elektroniniu ryšiu tinklu ir informacijos saugumo ìstatymo projektas, tačiau sis projektas taip ir nebuvo priimtas.

Tyrimo ribotumas - nors elektronines informacijos saugos teisinio reguliavimo analize gali büti atliekama lyginant ivairaus lygmens teisès aktus, tačiau tyrimas atliktas lyginant ir komentuojant tik pagrindinius, strateginius teises aktus, kibernetinio saugumo strategijas. 
Ǔ̌sienio valstybiu praktikos analize apsiribojo triju pagrindiniu pasirinktu valstybiu kibernetinio sangumo strategiju analize bei kitu autoriu atlikto tyrimo pristatymu. Tyrimo metu taip pat nebuvo detaliai analizuojamas teises normu kibernetinio saugumo srityje igyvendinimas.

Praktinè reikšme - tyrimo rezultatai gali büti pritaikomi kuriant naujas teisès normas ar atliekant egzistuojanciu teisés normu pakeitimus, kiek tai susije su kibernetiniu saugumu. Atsižvelgiant $\dot{i}$ išsakyta Kibernetinio saugumo programos kritika, ši programa galetu büti papildyta ir sukonkretinta. I nurodytas teisinio reguliavimo problemas galetu büti atsižvelgta ir kuriant nauja Kibernetinio saugumo istatymo projekta.

Originalumas / vertingumas - straipsnyje pristatomas tyrimas yra naujas Lietuvoje. Moksliniu darbu dèl kibernetinio saugumo teisinio reguliavimo (strategiju) kol kas trüksta ne tik Lietuvoje, bet ir užsienyje.

Raktažodžiai: kibernetinis saugumas, teisinis reguliavimas.

Tyrimo tipas: tyrimo pristatymas, požiūrio pristatymas.

\section{Ivadas}

Internetas (arba elektroninè erdvè) turi vis daugiau itakos kasdieniniam gyvenimui, taip pat ir globaliai ekonomikai. Šiuolaikinių organizacijų vidiniai valdymo procesai yra neịmanomi ir neịsivaizduojami be informacinių technologijų ir informacinių sistemų bei interneto prieigos. Interneto, informacinių technologijų plètra, informacijos perkèlimas į elektroninę erdvę didina informacinių procesų ir veiklos kokybę, užtikrina geresnị konkurencingumą bei efektyvumą. Informacija internete, anot P. Rosenzweigo, keičiamasi fiziniame pasaulyje precedento neturinčiu greičiu ir formomis ${ }^{1}$. Tačiau tai sukelia ir neigiamas pasekmes, tokias kaip svarbios elektroninès informacijos praradimas ar net skatina elektroninị nusikalstamumą. Elektroninès erdvės globalumas sukūrè beprecedentes sąlygas daryti nusikaltimus iš bet kurio pasaulio taško, kuriame yra internetas. Todèl labai svarbu apsisaugoti nuo elektroninių nusikaltimų, vykdomų pasitelkiant internetą. Kibernetinis saugumas tampa vienu iš pagrindinių tikslų, turint omenyje, kad grèsmės elektroninèje erdvejje kyla ne tik atskiriems vartotojams, bet net valstybėms. Kibernetinį saugumą Schjolberg ir Ghernaouti-Hele ịvardija kertiniu informacinès visuomenès akmeniu.

Joel P. Trachtman kibernetinị saugumą apibrěžia kaip apsaugą nuo netinkamo interneto infrastruktūros naudojimo ir piktnaudžiavimo (žlugdymo). Pagal D. Shoemakerị ir A. Conkliną, kibernetinis saugumas susijęs su procesų, susijusių su kylančių kibernetinių grèsmių identifikavimu bei sąnaudomis pagrịstų kontrapriemonių taikymu, kūrimu ir palaikymu². world. Library of Congress Cataloging, p. 22.

2 Shoemaker, D. and Conklin, A. 2012. Cybersecurity: the Essential body of knowledge. Course technology, p. 11. 
Kibernetinis saugumas - labai svarbi ir specifinè veiklos rūšis, kuri taip pat reikalauja nuoseklaus ir detalaus teisinio reglamentavimo. Vieni iš pagrindinių dokumentų šioje srityje - strateginiai dokumentai, kibernetinio saugumo strategijos ${ }^{3}$. Pastaruoju metu visos pasaulio valstybès vis daugiau dèmesio skiria kibernetiniam saugumui ir teisiniam reguliavimui, ne išimtis ir Lietuvos Respublika. Lietuva kibernetinio saugumo užtikrinimui yra prièmusi Elektroninès informacijos saugos (kibernetinio saugumo) plètros 2011-2019 metų programą ${ }^{4} .2012$ metais Europos Komisija prièmė vieną iš svarbiausių pastarojo meto dokumentų kibernetinio saugumo srityje - Kibernetinio saugumo strategiją, tai pat pasiūlè direktyvos projektą. Kai kuriose užsienio valstybėse pastaraisiais metais taip pat priimti strateginiai dokumentai kibernetinio saugumo srityje.

Todèl straipsnio tikslas - pristatyti pagrindinius strateginius pastarųų metų dokumentus kibernetinio saugumo srityje bei išanalizuoti pasirinktų užsienio valstybių kibernetinio saugumo strateginio teisinio reguliavimo praktiką. Tyrimo objektas - ES norminiai dokumentai - kibernetinio saugumo strategijos, pasirinktų valstybių kibernetinio saugumo strategijos ir Lietuvos kibernetinio saugumo programa. Tyrimo metodai: lyginamasis, teisinių dokumentų analizès, dedukcijos.

Kibernetinio saugumo strateginio teisinio reguliavimo klausimais užsienio mokslininkų darbų labai mažai, Lietuvoje D. Štitilis ir Ž. Paškauskas yra nagrinėję informacijos saugos strategiją iki 2008 metų. Naujoji ES kibernetinio saugumo strategija, taip pat Lietuvos kibernetinio saugumo programa praktiškai nenagrinètos.

\section{Europos Sąungos kibernetinio saugumo strategija}

Elektroninès informacijos sauga (kibernetinis saugumas) akcentuojama ne viename Europos Sajungos dokumente. Jau 2001 metais Europos Sajungos teisès aktuose yra nurodoma, kad informacinès ir telekomunikacinès technologijos tapo šiuolaikinès visuomenès gyvenimo kamienu ir nuo jų vis labiau yra priklausomi socialiniai ir ekonominiai visuomenès gerovès aspektai ${ }^{5}$, o 2006 metais atkreipé ypatingą dèmesi ị saugios Europos kibernetinès erdvès sukūrimą pasitelkiant visus socialinius valdžios partnerius $^{6}$. Didžiuliai informacijos kiekiai yra saugomi privačių įmonių duomenų centruose,

3 Mitrakas A. 2006. Information Security Law in Europe: Risks Checked . Information \& Communications Technology Law 15(1), p. 36.

4 Lietuvos Respublikos Vyriausybès 2011 m. birželio 29 d. nutarimas Nr. 796 „Dèl elektroninès informacijos saugos (kibernetinio saugumo) plètros 2011-2019 metais programos patvirtinimo“. Valstybès žinios. 2011, Nr. 83-4033; 2011, Nr.106 (atitaisymas).

5 Communication from the Commission to the Council, the European Parliament, the European Economic and Social Committee and the Committee of the Regions. Network and Information Security: Proposal for A European Policy Approach. COM/2001/298 [interaktyvus]. Briuselis, 2001 [žiūrèta 2013-05-20]. < http:// eur-lex.europa.eu/LexUriServ/site/en/com/2001/com2001_0298en01.pdf>.

6 Komisijos komunikatas Tarybai, Europos Parlamentui, Europos ekonomikos ir socialinių reikalų komitetui ir Regionų komitetui. Saugios informacinès visuomenès strategija - „Dialogas, partnerystè ir teisių suteikimas“.COM/2006/251 [interaktyvus]. Briuselis, 2006 [žiūrèta 2013-05-20].

$<\mathrm{http}$ ://eurlex.europa.eu/Notice.do?mode=dbl\&lang=en\&ihmlang=en\&lng1=en,lt\&lng2=cs,da,de,el,en,es,et ,fi,fr,hu,it,lt,lv,nl,pl,pt,sk,sl,sv,\&val=427504:cs>. 
valstybės institucijų duomenų saugyklose ir informacinių sistemų duomenų bazėse. Tokios informacijos paviešinimas, nesavalaikis panaudojimas ar sugadinimas gali sukelti didžiules problemas ir ženklius piniginius nuostolius verslo organizacijoms ar viešojo administravimo subjektams.

Europos Sajungos valstybės ypatingą dèmesị atkreipia ị tai, kad reikalingas glaudesnis Sajungos šalių narių bendradarbiavimas kovojant su nusikaltimais elektroninèje erdveje, taip pat užtikrinant kibernetinès erdvès bei „ypatingos svarbos informacinès infrastruktūros" apsaugą nuo kibernetinių išpuolių. Europos Sajungos dokumentuose pažymima, kad „ypatingos svarbos informacinès infrastruktūros objektai gyvybiškai būtini ES ekonomikos ir visuomenès plètrai“, o informacinių technologijų ir interneto plètra (skvarba) gerina ekonominius rodiklius, užtikrina visuomenès socialinės gerovès augimą bei piliečių gyvenimo kokybę.

Pastaraisiais metais Europos Sajungoje kibernetinio saugumo sričiai skiriamas ypatingas dėmesys. 2012 m. Europos Komisija paskelbè konsultaciją kibernetinio saugumo teisinio reguliavimo srityje. Konsultacijoje labai aktyviai dalyvavo tiek viešojo sektoriaus, tiek privataus sektoriaus subjektai.

2013 m. vasario 7 d. Europos Komisija ir Sajungos vyriausioji ịgaliotinè užsienio reikalams ir saugumo politikai paskelbej kibernetinio saugumo strategiją (toliau - Kibernetinio saugumo strategija) kartu su Komisijos direktyvos dèl tinklų ir informacinių sistemų saugumo pasiūlymu ${ }^{8}$.

Kibernetinio saugumo strategija „Atvira, saugi ir patikima kibernetinè erdvë“ yra išsami ES vizija, kaip geriausiai užirsti kelią kibernetinès veiklos sutrikdymui bei atakoms ir kokių atsakomujų priemonių imtis. Taip siekiama remti europines laisvès ir demokratijos vertybes ir užtikrinti saugų skaitmeninės ekonomikos augimą. Konkrečiais veiksmais siekiama didinti informacinių sistemų atsparumą elektroniniams nusikaltimams ir stiprinti ES tarptautinę kibernetinio saugumo politiką ir kibernetinę gynybą.

Išskiriami šie pagrindiniai kibernetinio saugumo principai ${ }^{9}$ :

\section{Pagrindiniu žmogaus teisių, nuomonès reiškimo laisvès, privatumo ir asmens duomenu apsauga}

Kibernetinis saugumas gali būti efektyvus tik tuo atveju, jei paremtas pagrindiniu teisių ir laisvių apsauga, taip pat grịstas esminėmis ES vertybėmis. Atitinkamai, individų teisès nageli būti užtikrintos be saugių tinklų ir sistemų. Bet koks informacijos

7 Joint Communication to the European Parliament, the Council, the European Ecomonic and Social Committee and the Committee of Regions „Cybersecurity strategy of the European Union: An Open, Safe and Secure Cyberspace, JOIN/2013/1 final [interaktyvus]. Briuselis, 2013 [žiūrèta 2013-05-20]. <http://ec.europa.eu/ information_society/newsroom/cf/dae/document.cfm?doc_id=1667>.

8 Proposal for a Directive of European parliament and the Council concerning measures to ensure a high common level of network and information security across the Union, COM/2013/48 final [interaktyvus]. Briuselis, 2013 [žiūrèta 2013-05-20]. <http://ec.europa.eu/information_society/newsroom/cff/dae/document. cfm?doc_id=1666>.

9 Joint Communication to the European Parliament, the Council, the European Ecomonic and Social Committee and the Committee of Regions „Cybersecurity strategy of the European Union: An Open, Safe and Secure Cyberspace, JOIN/2013/1 final. [interaktyvus]. Briuselis, 2013 [žiūrèta 2013-05-20]. <http://ec.europa.eu/ information_society/newsroom/cf/dae/document.cfm?doc_id=1667>, p. 1.2. 
dalinimasis kibernetinio saugumo tikslais, kai įtraukti asmens duomenys, turi būti vykdomas laikantis ES duomenų apsaugos reguliavimo ir užtikrinti visapusišką individų teisių apsaugą šioje srityje.

\section{Prieiga visiems}

Ribota prieiga prie interneto ar tokios prieigos nebuvimas sukelia nepatogumus piliečiams. Kiekvienas turi turèti prieigą prie interneto bei informacijos. Interneto integralumas bei saugumas turi būti garantuojamas, kad būtų užtikrinta saugi prieiga visiems.

\section{Demokratinis ir efektyvus valdymas}

Skaitmeninis pasaulis nėra kontroliuojamas vienos struktūros (bendrovès). Šiuo metu yra keletas ,žaidèjų“, kurių daugelis yra komerciniai arba nevyriausybiniai dariniai ir kurie įsitraukę ị kasdieninị interneto resursų valdymą, protokolų ir standartų internetui kūrimą. Pabrèžtina tokių ,žaidèjų“ svarba dabartiniame interneto valdymo modelyje ir parama šiam daugialypio valdymo požiūriui.

\section{Bendra atsakomybe užtikrinant sauguma}

Didejjanti priklausomybè nuo informacijos ir komunikacijų technologijų suponavo pažeidžiamas vietas, kurios turi būti išanalizuotos, sumažintos ir apgintos. Tiek viešasis sektorius, tiek privačios įmonès, tiek individualūs vartotojai turi pripažinti šią bendrą atsakomybę, imtis apsaugos priemonių ir, jei reikia, - užtikrinti koordinuotus veiksmus, siekiant sustiprinti kibernetinị saugumą.

Kibernetinio saugumo strategijoje akcentuojami penki strateginiai prioritetai ${ }^{\mathbf{1 0}}$ :

1. Pasiekti kibernetinị atsparumą;

2. Radikaliai sumažinti elektroninių nusikaltimų skaičių;

3. Sukurti kibernetinès gynybos politiką ir pajègumus, kiek tai susiję su bendra saugumo ir gynybos politika;

4. Plètoti pramonès ir technologinius išteklius, skirtus kibernetiniam saugumui užtikrinti;

5. Sukurti nuoseklią tarptautinę elektroninès erdvès politiką ir remti pagrindines ES vertybes.

Toliau kiekvienas iš šių prioritetų aptartinas atskirai.

\section{Pasiekti kibernetini atsparumą}

Norint užtikrinti kibernetinị atsparumą, tiek viešasis, tiek privatus sektorius turi tiek vystyti kibernetinio atsparumo galimybes, tiek glaudžiai bendradarbiauti tarpusavyje. Šiame kontekste paminètina ENISA, kuri buvo įkurta 2004 metais, taip pat daugelis teisinio reguliavimo priemonių, skirtų valdyti rizikas elektroniniuose ryšiuose ar apsaugoti asmens duomenis. Tačiau nepaisant visų priemonių, egzistuoja daugelis spragų vi-

10 Joint Communication to the European Parliament, the Council, the European Ecomonic and Social Committee and the Committee of Regions „Cybersecurity strategy of the European Union: An Open, Safe and Secure Cyberspace, JOIN/2013/1 final [interaktyvus]. Briuselis, 2013 [žiūrèta 2013-05-20]. <http://ec.europa.eu/ information_society/newsroom/cf/dae/document.cfm?doc_id=1667>, p. 2. 
soje ES, ypatingai susijusių su nacionaliniais pajėgumais tarptautinių incidentų atveju, taip pat susijusių su privataus sektoriaus įsitraukimu sprendžiant kibernetinio saugumo grèsmes. Dẻl to Kibernetinio saugumo strategija siejama su teisinio reguliavimo siūlymais, įskaitant:

- Minimalių bendrųų reikalavimų nacionalinėms informacijos infrastruktūroms sukūrimą. Valstybės narès būtų ịpareigotos paskirti kompetentingas institucijas, ikurti gerai veikiančius CERT, priimti nacionalines informacijos infrastruktūros strategijas ar atlikti kitus veiksmus.

- Ikurti koordinuotus prevencijos, aptikimo bei reagavimo mechanizmus, igalinančius dalintis informacija ir tarpusavyje bendradarbiauti kompetentingas nacionalines institucijas.

- Gerinti privataus sektoriaus įsitraukimą ir pasirengimą. Kadangi didžiają daugumą tinklų ir informacinių sistemų valdo privatūs subjektai / bendrovès, privataus sektoriaus įsitraukimas ị kibernetinio saugumo užtikrinimą yra kritiškai svarbus.

\section{Radikaliai sumažinti elektroninių nusikaltimu skaičiu}

Kuo daugiau gyvename skaitmeniniame pasaulyje, tuo daugiau sudarome galimybių elektroniniams nusikaltėliams veikti. Elektroniniai nusikaltimai yra viena iš labiausiai augančių nusikaltimų rūšių. Elektroniniai nusikaltėliai tampa vis pažangesni. Elektroniniai nusikaltimai santykinai pasižymi tuo, kad rizika dažniausiai maža, o pelnas didelis. Nusikaltèliai pasinaudoja tuo, kad elektroninèje erdvèje susekti nusikaltèlio pėdsakus yra gana sunku. Be to, elektroniniams nusikaltimams neegzistuoja valstybiu sienos. Dèl to teisésaugos institucijos turi bendradarbiauti tarpusavyje, keistis informacija ir veiksmais, tam kad duotų tinkamą atkirtị šiai augančiai grèsmei.

Dèl to teigiama, kad ES turi būti taikomi griežti ir efektyvūs įstatymai, nukreipti prieš elektroninius nusikaltimus. Paminètina, kad Konvencija dèl elektroninių nusikaltimų yra vienintelis teisiškai ịpareigojantis tarptautinis dokumentas elektroninių nusikaltimų srityje, kuris sukuria reikiamą sistemą prieš elektroninius nusikaltimus, kurią turi igyvendinti prie konvencijos prisijungusios valstybės. Tačiau ir Europos Komisija turi imtis atitinkamų veiksmų, įskaitant direktyvų ar kitų dokumentų elektroninių nusikaltimų srityje išleidimą / tobulinimą ar raginimą valstybes ratifikuoti Konvenciją dèl elektroninių nusikaltimų.

\section{Sukurti kibernetinès gynybos politika ir pajègumus, kiek tai susiję su bendra saugumo ir gynybos politika}

Kibernetinio saugumo pastangos ES taip pat apima ir kibernetinès gynybos dimensiją. Norint užtikrinti informacijos ir komunikacijos sistemų atsparumą, kibernetinès gynybos pajėgumų vystymas turi būti koncentruotas ị aptikimą, atsaką ir resursų atkūrimą po kibernetinių atakų. Šiame kontekste labai svarbi kibernetinès gynybos politika ir sugebejjimų duoti atkirti kibernetinėms atakoms vystymas. Ypatingai turi būti vystoma sinergija tarp privataus sektoriaus ir valstybinio sektoriaus tikslu apsaugoti kibernetinius resursus nuo kibernetinių atakų. 


\section{Plètoti pramonès ir technologinius išteklius, skirtus kibernetiniam saugumui uz̆tikrinti}

ES turi puikias tyrimo ir vystymo galimybes, tačiau dauguma pasaulio technologijų lyderių, kuriančiu inovatyvius ICT produktus ir paslaugas, yra įsikūrè už ES ribų. Dėl to kyla rizika, kad Europa pasidarys priklausoma nuo ICT produktų, kildinamų ne Europoje, taip pat nuo saugumo sprendimų, kildinamų ne iš Europos. Todèl Europoje daugiau turi būti vystomi kibernetinio saugumo sprendimai.

\section{Sukurti nuoseklią tarptautinę elektroninès erdvès politika ir remti pagrindines $E S$ vertybes}

Komisija turi vystyti tinkamą elektroninès erdvès politiką, kuri užtikrintų geresnị tarptautinių partnerių ir organizacijų įsitraukimą ir glaudesnį bendradarbiavimą, taip pat glaudesnius ryšius su bendruomenemis ir privačiu sektoriumi.

Vienas iš pagrindinių ES tarptautinès elektroninès erdvés politikos aspektų būtụ skatinti, kad elektroninè erdvė būtų laikoma laisvès vieta, taip pat vieta, kurioje pasireiškia žmogaus teisès ir laisvès.

\section{Funkcijos ir atsakomybès pagal ES Kibernetinio saugumo strategiją}

Šiuolaikinèje visuomenèje kibernetiniai incidentai neturi sienų. Visi dalyviai, tiek nacionaliniu, tiek ES lygiu, turi dirbti kartu, siekiant užtikrinti kibernetinị saugumą. Kadangi gali būti taikomi skirtingi teisès aktai ir skirtingos jurisdikcijos, vienas iš pagrindinių ES uždavinių yra išgryninti visų pagrindinių ,žaidejjų“ vaidmenis ir atsakomybes.

Šiuo metu centralizuotos europinès priežiūros koncepcija nepalaikoma. Manoma, kad nacionalinès vyriausybės yra geriausia, kas gali organizuoti kibernetinių atakų prevenciją bei atsaką $i$ šias atakas, taip pat sukurti ryšius su privačiu sektoriumi. Be abejo, dèl galimos tarptautinès rizikų kilmès efektyvus nacionalinis atsakas dažnai reikalautų ES lygio įsitraukimo.

ES kibernetinio saugumo strategijoje yra išskiriami trys lygiai, kuriais būtų veikiama, siekiant užtikrinti kibernetinį saugumą: nacionalinis lygis, ES lygis ir tarptautinis lygis.

Nacionaliniu lygiu teigiama, kad valstybès narès turi turèti atitinkamas struktūras elektroninių nusikaltimų ir gynybos srityje. Šios struktūros turètų užtikrinti reikiamus pajègumus kovojant su kibernetiniais incidentais. Koordinavimo veiklą šioje srityje turètų vykdyti ministerijos. Kibernetinio saugumo strategijose valstybès narès turètu nustatyti ịvairių nacionalinių institucijų funkcijas. Taip pat turètų būti užtikrinamas reikiamas apsikeitimas informacija ne tik tarp valstybès institucijų, bet ir su privačiu sektoriumi. Kibernetinių incidentų atveju turètų būti užtikrinamas atitinkamų saugumo planų veikimas, įskaitant ir atitinkamų funkcijų bei atsakomybių nustatymą.

ES mastu taip pat yra nemažai institucijų, veikiančių kibernetinio saugumo srityje. Atitinkamai, ENISA, Europolas ir EDA yra institucijos, aktyviai veikiančios kibernetinio saugumo srityje. Ypač svarbus yra bendradarbiavimas tarp šių institucijų tokiose srityse kaip rizikos valdymas, mokymai, apsikeitimas geriausia praktika ir kt. 
Tarptautiniu mastu labai svarbu koordinuoti tarpusavio veiksmus kibernetinio saugumo srityje. Tarptautiniu mastu Europos Komisija remia pagrindines vertybes ir palaiko viešą bei skaidrų kibernetinių technologijų naudojimą. Europos Komisija taip pat pasisako už bendradarbiavimą su pagrindiniais tarptautiniais partneriais ir organizacijomis: Europos Taryba, EBPO ir kt.

Pasiūlyta tinklų ir informacinių sistemų saugumo direktyva (projektas) yra pagrindinè bendrosios strategijos sudedamoji dalis, todèl reikès, kad visos valstybès narès, pagrindiniai interneto teikejjai ir ypatingos svarbos infrastruktūros objektų, pavyzdžiui, e. prekybos platformų ir socialinių tinklų, operatoriai ir energijos, transporto, bankininkystės ir sveikatos priežiūros paslaugų operatoriai užtikrintų saugią ir patikimą skaitmeninę aplinką visoje ES. Pasiūlytoje direktyvoje nustatytos šios priemonėe ${ }^{11}$ :

a) valstybės narès turi priimti tinklų ir informacinių sistemų saugumo strategiją ir paskirti nacionalinę tinklų ir informacinių sistemų saugumo kompetentingą instituciją, kuri turètų tinkamų finansinių ir žmogiškuju išteklių užkirsti kelią tinklų ir informacinių sistemų saugumo rizikai ir incidentams, juos spręsti ir imtis atsakomųų priemonių;

b) sukurti valstybių narių ir Komisijos bendradarbiavimo mechanizmą: saugia infrastruktūra būtų iš anksto pranešama apie riziką ir incidentus, bendradarbiaujama ir reguliariai rengiami tarpusavio vertinimai;

c) kai kurių sektorių (finansinių paslaugų, transporto, energetikos, sveikatos priežiūros) ypatingos svarbos infrastruktūros objektų operatoriai, informacinès visuomenès paslaugų teikejjai (visų pirma programinès ịrangos parduotuvių e. prekybos platformų, mokèjimo internetu, nuotolinių kompiuterinių išteklių paslaugų, paieškos sistemų, socialinių tinklų) ir viešojo administravimo institucijos turi patvirtinti rizikos valdymo praktiką ir pranešti apie pagrindinius saugumo incidentus savo pagrindinèse tarnybose.

\section{Kai kurių užsienio valstybių patirtis reglamentuojant kibernetinị saugumą (strateginiai dokumentai)}

Nors ES kibernetinio saugumo strategija ir direktyva dar nepatvirtinta ir atitinkamose ES valstybèse neigyvendinta, reikia paminèti, kad, nepaisant to, kai kuriose pasaulio valstybèse jau yra priimtos kibernetinio saugumo strategijos. $2013 \mathrm{~m}$. balandžio mènesi 13 ES valstybių buvo pasitvirtinusios nacionalines kibernetinio saugumo strategijas. Jungtinès Karalystės kibernetinio saugumo strategijos apžvalgoje ${ }^{12}$ buvo išnagrinètos ir palygintos devynių valstybių ${ }^{13}$ kibernetinio saugumo strategijos. Šių valstybių kibernetinio saugumo strategijos buvo lygintos su JK kibernetinio saugumo strategija. Palyginimo išvadose pateikti rezultatai liudija, kad JK kibernetinio saugumo strategija

11 Proposal for a Directive of European parliament and the Council concerning measures to ensure a high common level of network and information security across the Union, COM/2013/48 final [interaktyvus]. Briuselis, 2013 [žiūrèta 2013-05-20]. <http://ec.europa.eu/information_society/newsroom/cf/dae/document. cfm?doc_id=1666>, art. 5.

12 The UK cyber security strategy: Landscape review [interaktyvus]. 2013 [žiūrèta 2013-05-20]. <http://www. nao.org.uk/report/the-uk-cyber-security-strategy-landscape-review/>.

13 Australija, Kinija, Estija, Prancūzija, Vokietija, Indija, Japonija, Rusija ir JAV. 
išsiskiria „svoriu“, kurị strategijai suteikė JK vyriausybė su tikslu sudaryti saugias sąlygas elektroninei komercijai bei kitiems svarbiems santykiams. Keletas kitų rezultatų:

- Keturios valstybės, kaip ir JK, kibernetinio saugumo programose yra nustačiusios tikslą kovoti su elektroniniais nusikaltimais;

- Visos tirtos valstybès kelia tikslą gerinti atsparumą kibernetinèms atakoms ir saugoti nacionalinị saugumą;

- Tik viena valstybé, taip pat ir JK, palaiko atviros visuomenės idėją;

- Visos valstybès kelia tikslą vystyti kibernetinio saugumo žinias bei pajègumus užtikrinant kibernetinị saugumą.

Detaliau palygintinos trijų valstybių kibernetinio saugumo strategijos ${ }^{14}$ : Jungtinès Karalystès, Vokietijos ir Prancūzijos.

Jungtinès Karalystès kibernetinio saugumo strategija ${ }^{15}$ „Jungtinės Karalystès apsauga ir palaikymas skaitmeniniame pasaulyje" patvirtinta $2011 \mathrm{~m}$. lapkričio mėnesị. Strategijoje nustatyta kibernetinio saugumo vizija 2015 metams: iš energingos, tvirtos ir saugios elektroninès erdvès gauti didžiulę ekonominę ir socialinę vertę, kur šalies veiksmai, valdomi šalies esminių laisvès vertybių, teisingumo, skaidrumo ir ịstatymų galios, didins gerovę, nacionalinị saugumą ir tvirtą visuomenę ${ }^{16}$. Kad igyvendintų šią viziją iki numatyto termino, Jungtinė Karalystė pateikia šiuos keturis tikslus:

1. Kovoti su elektroniniais nusikaltimais Jungtinèje Karalystëje ir tapti viena iš saugiausių šalių pasaulyje verslui elektroninėje erdvèje vystyti;

2. Būti atsparesnei kibernetiniams išpuoliams ir gebėti geriau apsaugoti savo interesus elektroninėje erdvėje;

3. Jungtinè Karalystè, padedanti formuoti atvirą, stabilią ir energingą elektroninę erdvę, kurią šalies visuomené galès saugiai naudoti, kas palaikytų atviras visuomenes;

4. Jungtinè Karalystė, turinti puikias žinias, ịgudžius ir gebėjimus, leidžiančius palaikyti visus išsikeltus tikslus elektroninès erdvės saugumui užtikrinti.

Vokietijos kibernetinio saugumo strategija ${ }^{17}$ patvirtinta $2011 \mathrm{~m}$. vasario mènesị. Strategijoje nenustatytos datos, todèl galima daryti išvadą, kad strategija bus aktuali iki kitos strategijos patvirtinimo arba iki esamos strategijos atnaujinimo. Vokietijos strategijoje išskiriami šie pagrindiniai elektroninès erdvès saugumo strateginiai tikslai ir priemonès saugumui užtikrinti ${ }^{18}$ :

14 Šios valstybès pasirinktos ekspertiniam vertinimui kaip valstybės, kuriose daugiausia pažengęs kibernetinis saugumas ir jo teisinis reguliavimas.

15 UK cybersecurity strategy. Protecting and promoting the UK in a digital world [interaktyvus]. 2011 [žiūrèta 2013-05-20]. <http://www.carlisle.army.mil/dime/documents/UK\%20Cyber\%20Security\%20Strategy.pdf>.

16 UK cybersecurity strategy Protecting and promoting the UK in a digital world [interaktyvus]. 2011 [žiūrèta 2013-05-20]. <http:/www.carlisle.army.mil/dime/documents/UK\%20Cyber\%20Security\%20Strategy.pdf>, p. 7.

17 Cybersecurity Strategy for Germany [interaktyvus]. 2011 [žiūrèta 2013-05-20]. <https://www.bsi.bund. de/SharedDocs/Downloads/EN/BSI/Publications/CyberSecurity/Cyber_Security_Strategy_for_Germany. pdf?_blob=publicationFile $>$.

18 Cybersecurity Strategy for Germany [interaktyvus]. 2011 [žiūrèta 2013-05-20]. <https://www.bsi.bund. de/SharedDocs/Downloads/EN/BSI/Publications/CyberSecurity/Cyber_Security_Strategy_for_Germany. pdf?_blob=publicationFile>, p. 7-12. 
1. Ypatingos svarbos informacinių struktūrų apsauga;

2. Saugios informacinès technologijos (toliau - IT) Vokietijoje;

3. IT apsaugos stiprinimas viešojo valdymo sektoriuje;

4. Nacionalinis reagavimo ị kibernetines nelaimes centras;

5. Nacionalinè kibernetinès erdvès apsaugos taryba;

6. Efektyvi nusikaltimų kontrolè, taip pat ir kibernetinèje erdvèje;

7. Efektyvūs koordinuoti veiksmai siekiant užtikrinti kibernetinị saugumą Europoje ir pasaulyje;

8. Patikimų ir vertų pasitikejimo informacinių technologijų naudojimas;

9. Personalo plètra federalinèje valdžioje;

10. Reagavimo ị kibernetinius išpuolius ịrankiai.

Prancūzijos informacinių sistemų gynybos ir saugumo strategija ${ }^{19}$ priimta $2011 \mathrm{~m}$. vasarị. Strategijoje taip pat neminimos konkrečios datos. Prancūzijos strategijoje nurodyti šie pagrindiniai strategijos tikslai ${ }^{20}$ :

1. Igyti pasaulinę galią kibernetinès gynybos srityje;

2. Apsaugoti Prancūzijos gebejjimą priimti sprendimus apsaugant informaciją, susijusią su jos suverenitetu;

3. Stiprinti svarbiausių nacionalinių infrastruktūrų kibernetinị saugumą;

4. Užtikrinti elektroninès erdvės saugumą.

Išnagrinejjus ir apibendrinus minėtų valstybių kibernetinio saugumo strategijų nuostatas, galima pastebèti, kad visos valstybès kelia šiuos pagrindinius klausimus:

- glaudaus bendradarbiavimo tiek nacionaliniu, tiek tarptautiniu lygiu bei informacijos keitimosi;

- kritinès informacinès infrastruktūros apsaugos;

- visuomenès informavimo;

- IT apsaugos stiprinimo viešajame sektoriuje;

- saugių IT naudojimo ir kt.

Šios strategijos ir jų nuostatos galètų būti pavyzdžiu kitoms valstybėms kuriant kibernetinio saugumo strategijas.

Paminètina, jog be šių strategijų, kurios buvo priimtos beveik vienu metu, Vokietijoje 2013 metais jau yra parengtos ir siūlomos priimti ịstatymo nuostatos dèl kibernetinio saugumo.

\section{Iniciatyvos Lietuvoje kibernetinị saugumą reglamentuoti istatymo lygmeniu}

Užuomazgos kibernetinio saugumo teisiniam reguliavimui įstatymu Lietuvoje kilo jau 2006 metais, kai Lietuvos Respublikos Vyriausybė nutarimu Nr. 1211 patvirtino

19 France information systems defence and security strategy [interaktyvus]. 2011 [žiūrèta 2013-05-20]. <http:// www.ssi.gouv.fr/IMG/pdf/2011-02-15_Information_system_defence_and_security_-_France_s_strategy. pdf>.

20 France information systems defence and security strategy [interaktyvus]. 2011 [žiūrèta 2013-05-20]. <http:// www.ssi.gouv.fr/IMG/pdf/2011-02-15_Information_system_defence_and_security_-_France_s_strategy. pdf>, p. 7-11. 
Lietuvos Respublikos elektroninių ryšių tinklų ir informacijos saugumo įstatymo koncepciją ${ }^{21}$. Lietuvos Respublikos elektroninių ryšių tinklų ir informacijos saugumo įstatymo koncepcija parengta igyvendinant Lietuvos Respublikos Vyriausybès 2006-2008 metų programos igyvendinimo priemonių, patvirtintų Lietuvos Respublikos Vyriausybės 2006 m. spalio 17 d. nutarimu Nr. 1020 (Žin., 2006, Nr. 112-4273), 157 punktą.

Šioje koncepcijoje buvo numatyta, jog ,Lietuvos Respublikos elektroniniu ryšiu tinklu ir informacijos saugumo istatymas reglamentuos santykius, susijusius su elektroninių ryšiu tinklu ir informacijos saugumu (toliau vadinama - tinklu ir informacijos saugumas), sudarys salygas saugios informacinés visuomenès plètrai, didins vartotoju pasitikejjima informacine visuomene ${ }^{\text {"222 }}$. Svarbiausias įstatymo tikslas pagal koncepciją turèjo būti toks - apibrèžti ir įtvirtinti visuomeninių santykių, susijusių su tinklų ir informacijos saugumu, teisinio reguliavimo pagrindus. İstatymas užpildys ir su elektroninių ryšių paslaugų teikimu susijusių santykių teisinio reguliavimo spragas, kiek tai susiję su tinklų ir informacijos saugumu teikiant elektroninių ryšių paslaugas.

Istatyme pagal Koncepciją turèjo būti numatyta:

- ,aiški valstybés institucijų struktūra tinklu ir informacijos saugumo srityje, kad nebūtu dubliuojamos instituciju funkcijos ir atsakingos institucijos veiksmingai bendradarbiautu;

- nustatyti bendrieji tinklu ir informacijos saugumo reikalavimai, daugiausia skirti vartotojams apsaugoti nuo tinklu ir informacijos saugumo incidentu;

- valstybès ir savivaldybiu instituciju tinklu ir informaciniu sistemu, saugaus informacijos perdavimo tarp valstybès ir savivaldybiu instituciju, kritiniu informaciniu infrastruktūru tinklu ir informacijos saugumo reikalavimai;

- aiški tinklu ir informacijos saugumo lygio ìvertinimo sistema, reglamentuojanti tinklu ir informacijos saugumo audito atlikima, techninès ir programinès ìrangos saugumo ìvertinimą. Ši sistema daugiausia bus taikoma valstybes ir savivaldybiu instituciju tinklams ir informacinèms sistemoms, kritinèms informacinèms infrastruktūroms, didesniu ìmoniu, taip pat informacinès visuomenès paslaugu teikeju tinklams ir informacinèms sistemoms - t. y. tais atvejais, kai tinklu ir informacijos saugumas daugiausia užtikrinamas laikantis atitinkamos saugumo politikos. " 23

Po šios koncepcijos patvirtinimo buvo pradètas rengti ir Lietuvos Respublikos elektroninių ryšių tinklų ir informacijos saugumo įstatymo projektas. Buvo sudaryta darbo grupé šio ịstatymo projektui rengti. Darbo grupe įstatymo variantą parengè, tačiau įstatymas taip ir nebuvo priimtas. Pagal projektą, įstatymas turèjo reglamentuoti visuomeninius santykius, susijusius su elektroninių ryšių tinklų ir informacijos saugumu, nustatant bendruosius reikalavimus elektroninių ryšių tinklų ir informacijos saugumui užtikrinti, taip pat visuomeninius santykius, susijusius su valstybės ir vietos savivaldos

21 Lietuvos Respublikos Vyriausybės nutarimas Nr. 1211 „Dėl Lietuvos Respublikos elektroninių ryšių tinklų ir informacijos saugumo ịstatymo koncepcijos patvirtinimo“. Valstybés žinios. 2006, Nr. 134-5081.

22 Ibid., 2 p.

23 Lietuvos Respublikos Vyriausybès nutarimas Nr. 1211 „Dėl Lietuvos Respublikos elektroninių ryšių tinklų ir informacijos saugumo įstatymo koncepcijos patvirtinimo“. Valstybès žinios. 2006, Nr. 134-5081, 41 p. 
institucijų bei kritinių informacinių infrastruktūrų elektroninių ryšių tinklų ir informacijos saugumu bei elektroninių ryšių tinklų ir informacijos saugumo audito bei techninès ir programinès įrangos saugumo vertinimu.

Šiuo metu Lietuvoje nèra galiojančio įstatymo, holistiškai reguliuojančio kibernetinio saugumo sritị. Tam tikros įstatymo nuostatos numatytos Lietuvos Respublikos valstybès informacinių išteklių įstatyme ${ }^{24}$, tačiau yra reglamentuota tik valstybès informacinių išteklių sauga bei saugos ịgaliotinio institutas. Šios įstatymo teisès normos, deja, nereglamentuoja informacijos saugos privačiame sektoriuje, o ir informacijos sauga valstybès institucijų sektoriuje reglamentuojama fragmentiškai, pavyzdžiui, įstatyme nenumatyta informacijos saugos institucinès kontrolès ir politikos šioje srityje formavimo sistema. Tai kad teisès aktuose nèra ịvardinta nė viena už informacijos saugumo koordinavimą atsakinga institucija, turinti igaliojimus ir resursus ne tik rengti ar vertinti teisès aktus, bet ir vykdyti realius informacijos saugumo auditus, kaip problemą kelia ir dr. Saulius Jastiuginas ${ }^{25}$.

\section{Lietuvos kibernetinio saugumo strategija}

Elektroninès informacijos saugos teisinis reguliavimas strategijos forma prasidejo nuo 2006 m., kai buvo patvirtinta Elektroninès informacijos saugos valstybès institucijų informacinèse sistemose valstybinè strategija, kuri galiojo nuo 2006 m. iki 2008 m. 2008 m. Lietuvos Elektroninès informacijos saugos valstybės institucijų informacinèse sistemose valstybiné strategija iki 2008 metų $^{26}$ (toliau - Valstybinè strategija) ir jos igyvendinimo priemonių planas Lietuvos Respublikos Vyriausybės nutarimu Nr. 601 buvo patvirtinti $2006 \mathrm{~m}$. birželio $19 \mathrm{~d}$. Jau iš strategijos pavadinimo tapo aišku, kad Valstybinè strategija buvo skirta išimtinai valstybès institucijų sektoriui. Valstybinès strategijos pagrindiniai numatyti pasiekti tikslai buvo tokie:

- „tobulinti elektroninès informacijos saugos koordinavima ir priežiūrą. Šiam tikslui pasiekti numatyti tokie uždaviniai: užtikrinti elektroninès informacijos saugos koordinavima; sukurti efektyvia kovos su nusikalstamomis veikomis, vykdomomis elektroninés informacijos perdavimo aplinkoje, sistema;

- teisès aktais reguliuoti elektroninès informacijos sauga. Šiam tikslui pasiekti numatyti tokie uždaviniai: priimti teisés aktus, reguliuojančius elektroninès informacijos sauga; elektroninès informacijos sauga nustatyti saugos dokumentuose;

24 Lietuvos Respublikos valstybės informacinių išteklių įstatymas Nr. XI1807. Valstybès žinios. 2011, Nr. 1637739; V skyrius

25 VU mokslininkas: informacijos saugumo klausimą reikia kelti jau šiandien. Technologijos.lt [interaktyvus]. 2013-03-06 [žiūrèta 2013-05-20]. <http://www.technologijos.lt/n/technologijos/it/S-31575/straipsnis/VUmokslininkas-informacijos-saugumo-klausima-reikia-kelti-jau-siandien?l=2\&p=1 >.

26 Lietuvos Respublikos Vyriausybès nutarimas Nr. 601 „Dèl elektroninès informacijos saugos valstybės institucijų informacinėse sistemose strategijos iki 2008 metų ir jos igyvendinimo priemonių plano patvirtinimo“. Valstybès žinios. 2006, Nr. 70-2575. 
- $\quad$ kelti elektroninès informacijos saugos kultūrą. Šiam tikslui pasiekti numatyti tokie uždaviniai: mokyti elektroninès informacijos saugos valstybés tarnautojus ir darbuotojus, dirbančius pagal darbo sutartis; skatinti elektroninès informacijos saugos svarbos suvokima;

- tobulinti elektroninés informacijos perdavimo infrastruktūros saugą. Šiam tikslui pasiekti numatytas uždavinys - tobulinti saugiame valstybiniame duomenu perdavimo tinkle saugomos ir perduodamos elektroninés informacijos sauga;

- $\quad$ bei skatinti elektroninès informacijos saugos užtikrinimo projektu igyvendinimą. Šiam tikslui pasiekti numatytas uždavinys - naudotis privataus sektoriaus patirtimi, igyvendinant elektroninès informacijos saugos projektus. "27

Reikia pasakyti, kad, nepaisant šioje strategijoje užsibrėžtų pasiekti tikslų, uždavinių, skirtų šiems tikslams pasiekti, formuluotès buvo gana deklaratyvios, abstrakčios ir nekonkrečios ${ }^{28}$.

Minima Valstybinè strategija nustojo galioti 2008 metais ir po šios datos Lietuvoje nebuvo jokios galiojančios informacijos saugos strategijos ar programos.

Lietuvos Respublikos Vyriausybės 2011 m. birželio 29 d. nutarimu Nr. 796 „Dèl elektroninès informacijos saugos (kibernetinio saugumo) plètros 2011-2019 metais programos patvirtinimo" buvo patvirtinta Kibernetinio saugumo plètros programa 2011-2019 metams ${ }^{29}$ (toliau - Kibernetinio saugumo programa). Atkreiptinas dèmesys, kad Kibernetinio saugumo programa buvo patvirtinta dar 2011 m., kai Europos Komisija dar net nebuvo paskelbusi konsultacijos dèl ES kibernetinio saugumo strategijos, todèl Kibernetinio saugumo programa formaliai nederinta su ES kibernetinio saugumo strategija.

Kibernetinio saugumo programa parengta atsižvelgiant ị tai, kad „valstybès ir visuomenès gyvenime vis didesne reikšme igyja informacinèmis ir ryšiu technologijomis tvarkoma ir perduodama elektronine informacija, atsiradusios elektroninès informacijos tvarkymo galimybès paskatino nacionaliniu ir globaliu informaciniu visuomeniu atsiradima ir sudarè salygas toliau modernizuoti šaliu ūkius ir efektyviau valdyti valstybę, tačiau tuo pačiu metu i elektronine forma perkeliama vis daugiau informacijos, sparčiai automatizuojami ịvairūs šalies valdymo ir ūkio veiklos procesai, globali kibernetinè erdve ir joje teikiamos viešosios paslaugos tapo patraukliu atskiru asmenu, nusikalstamu grupuočiu, politiniu jëgu ir kitu subjektu taikiniu“‘30.

Programos paskirtis - „,nustatyti elektronines informacijos saugos (kibernetinio saugumo) plètros tikslus ir uždavinius, kad būtų užtikrintas elektroninès informacijos

27 Lietuvos Respublikos Vyriausybès nutarimas Nr. 601 „Dèl elektroninès informacijos saugos valstybès institucijų informacinėse sistemose strategijos iki 2008 metų ir jos įgyvendinimo priemonių plano patvirtinimo“. Valstybès žinios. 2006, Nr. 70-2575, 9 p.

28 Štitilis, D. ir Paškauskas, Ž. 2007. Valstybès elektroninès informacijos saugos strategija - vienas iš pagrindiniu elektroninès informacijos saugos reguliavimo instrumentų: lyginamoji analizè. Jurisprudencija. 2(92): 41.

29 Lietuvos Respublikos vyriausybės 2011 metų birželio 29 dienos nutarimas Nr. 796 „Dèl elektroninès informacijos saugos (kibernetinio saugumo) plètros 2011-2019 metais programos patvirtinimo“. Valstybès žinios. 2011, Nr. 83-4033; 2011, Nr. 106 (atitaisymas).

30 Lietuvos Respublikos Vyriausybès 2011 m. birželio 29 d. nutarimas Nr. 796 „Dèl elektroninès informacijos saugos (kibernetinio saugumo) plètros 2011-2019 metų programos patvirtinimo“. Valstybès žinios. 2011, Nr. 83-4033; 2011, Nr. 106 (atitaisymas), 1 p. 
ir kibernetineje erdveje teikiamu paslaugu konfidencialumas, vientisumas ir prieinamumas, elektroniniu ryšiu tinklu, informaciniu sistemu ir ypatingos svarbos informacinès infrastruktūros apsauga nuo incidentu ir kibernetiniu ataku, asmens duomenu ir privatumo apsauga, taip pat nustatyti uždavinius, kuriu igyvendinimas leistu užtikrinti bendra kibernetinès erdvès ir joje veikla vykdančiu subjektu saugumą“31.

Programos strateginis tikslas -,,plètoti elektroninès informacijos sauga Lietuvoje, užtikrinti kibernetini sauguma ir pasiekti, kad 2019 metais teisès aktu nustatytus elektroninès informacijos saugos (kibernetinio saugumo) reikalavimus atitinkančiu valstybès informaciniu ištekliu dalis pasiektu 98 procentus visu valstybès informaciniu ištekliu, vidutinis ypatingos svarbos informacinès infrastruktūros incidentu likvidavimo laikas sumažètu iki 0,5 valandos, o Lietuvos gyventoju, kurie saugiai jaučiasi kibernetinejje erdveje, dalis pasiektu 60 procentu“"32.

Nustatyti šie Kibernetinio saugumo programos igyvendinimo tikslai ${ }^{33}$ :

1. Pasiekti, kad bütu užtikrintas valstybès informaciniu ištekliu saugumas.

Kibernetinio saugumo programoje pažymima, kad nesukurta kibernetinio saugumo valdymo sistema, tačiau nèra reglamentuojama, kaip tokią sistemą reikètų sukurti. Tai pat rašoma, kad trūksta privataus ir viešojo sektorių bendradarbiavimo, tačiau nereglamentuojama, kaip tokị bendradarbiavimą reikètų skatinti ir / ar ịgyvendinti.

2. Užtikrinti veiksminga ypatingos svarbos informacinès infrastruktūros funkcionavima.

Kibernetinio saugumo programoje pažymima, kad tokios infrastruktūros saugumas užtikrinamas tik atskirose organizacijose ir nėra koordinuojamas, nenustatyti tarpusavio ryšiai ir nevertinamas poveikis nacionaliniu mastu.

3. Siekti užtikrinti Lietuvos gyventoju ir asmenu, esančiu Lietuvoje, sauguma kibernetineje erdveje.

Kaip teigiama Kibernetinio saugumo programoje, ,kibernetinès erdvès saugumui užtikrinti būtina nenutrūkstamai veikianti ir tinkamai valdoma sistema, apimanti visa incidentu gyvavimo cikla: išankstinio perspejjimo, prevencijos, aptikimo, likvidavimo ir tyrimo fazes. Siekiant kovoti su kenksminga programine ịranga nuotoliniu būdu valdomu kompiuteriu tinklais ar kitais kenkejjiškos veiklos kibernetinejje erdveje büdais, veiksminga blokuoti interneto prieiga kenkejišsk veikla vykdantiems asmenims ir (ar) ìrenginiams. Šiuo metu visuomeneje yra susiformavęs stereotipas dèl nebaudžiamumo už neteisètus veiksmus kibernetinejje erdveje, todèl svarbu šị stereotipa panaikinti“‘34.

31 Lietuvos Respublikos Vyriausybès 2011 m. birželio 29 d. nutarimas Nr. 796 „Dèl elektroninės informacijos saugos (kibernetinio saugumo) plètros 2011-2019 metais programos patvirtinimo“. Valstybès žinios. 2011, Nr. 83-4033; 2011, Nr. 106 (atitaisymas), 2 p.

32 Lietuvos Respublikos Vyriausybės 2011 m. birželio 29 d. nutarimas Nr. 796 „Dèl elektroninės informacijos saugos (kibernetinio saugumo) plètros 2011-2019 metais programos patvirtinimo“. Valstybés žinios. 2011, Nr. 83-4033; 2011, Nr. 106 (atitaisymas), 3 p.

33 Lietuvos Respublikos Vyriausybès 2011 m. birželio 29 d. nutarimas Nr. 796 „Dèl elektroninės informacijos saugos (kibernetinio saugumo) plètros 2011-2019 metais programos patvirtinimo“. Valstybés žinios. 2011, Nr. 83-4033; 2011, Nr. 106 (atitaisymas), II skyrius.

34 Lietuvos Respublikos Vyriausybès 2011 m. birželio 29 d. nutarimas Nr. 796 „Dèl elektroninės informacijos saugos (kibernetinio saugumo) plètros 2011-2019 metais programos patvirtinimo“. Valstybès žinios. 2011, Nr. 83-4033; 2011, Nr. 106 (atitaisymas), 6.3 p. 
Kiekvienam tikslui keliami ir atitinkami uždaviniai. Visa tai pasiekti įmanoma tik turint pakankamai gerai parengtus specialistus, kurių igytas išsilavinimas būtų glaudžiai susijęs su informacinių technologijų ir informacijos saugumo vadyba. Lietuvos Respublikos Vyriausybės nutarime yra pažymima, kad jau šiuo laiku yra jaučiamas kvalifikuotų informacijos saugos specialistų trūkumas ir numatoma, kad ateityje tas trūkumas tik dar labiau didès. Tokių specialistų trūkumas taip pat yra akcentuojamas ir Europos Sajungos dokumentuose.

Paminètina, kad kibernetinio saugumo programos vertinimo kriterijai ir jų reikšmès pateikiami šios programos priede. Kibernetinio saugumo programos ịgyvendinimą koordinuoja Lietuvos Respublikos vidaus reikalų ministerija, o už programos tikslų ir uždavinių igyvendinimą atsako priede nurodytos institucijos ir įstaigos.

Analizuojant Lietuvos kibernetinio saugumo programą ES kibernetinio saugumo strategijos bei direktyvos, taip pat kitų nagrinètų užsienio valstybių kibernetinio saugumo strategijų kontekste pažymètina, kad programa neužtikrina visapusiškos Lietuvos kibernetinio saugumo strategijos, kol kas neatitinka visų Europos Komisijos projekte nustatytų kibernetinio saugumo prioritetų, taip pat neužtikrina kitų valstybių kibernetinio saugumo strategijose numatytų kai kurių svarbiausių tikslų ir uždavinių.

Pirma, programoje nenumatytos priemonès dèl valstybės ir privataus sektoriaus bendradarbiavimo kibernetinio saugumo srityje. Turint omenyje, kad šiuo metu didžioji dauguma infrastruktūros priklauso privačiam sektoriui, toks bendradarbiavimas būtinas.

Antra, programoje per mažai dėmesio skiriama elektroniniams nusikaltimams ir jų skaičiaus mažinimui. Elektroninių nusikaltimų latentiškumas, kaip rodo tyrimai, yra didžiulis. Elektroniniai nusikaltimai yra kibernetinių atakų pavadinimas baudžiamosios teisès kontekste, todèl šiai nusikaltimų rūšiai programoje turètų būti skiriamas deramas dèmesys.

Trečia, programoje nenumatyta išsami ir sisteminė kibernetinės gynybos politika. Šiuo metu Lietuvoje nėra nustatyta, kokie veiksmai turi būti vykdomi kilus kibernetinèms grèsmėms, kokios yra atskirų ,žaidèjų“ funkcijos ir atsakomybės, kokie prioritetai saugant kritinę infrastruktūrą nuo kibernetinių atakų, kokie institucijų ir privataus sektoriaus veiksmai kibernetinių atakų atveju. Šị trūkumą būtina kuo skubiau šalinti.

Ketvirta, programoje neaptariami instituciniai klausimai, nedetalizuojamos atitinkamų institucijų funkcijos ir atsakomybès kibernetinio saugumo srityje.

Penkta, programoje nenumatyti tikslai ir uždaviniai, susiję su visuomenès informavimu ir švietimu, kas yra būtina šiuolaikinèje informacinèje visuomenèje, nes kibernetinio saugumo grèsmės dažnai susijusios su galutiniais interneto vartotojais.

Paminètina, kad strategijoje iškelti tikslai ir uždaviniai nepakankamai konkretūs, abstraktūs, ne visais atvejais atspindi elektroninès erdvès keliamus pavojus bei rizikas. Tikslams ir uždaviniams pasiekti nėra sukurta kibernetinio saugumo valdymo koordinavimo sistema, taip pat nėra numatytas konkrečių lèšu skyrimas.

Kaip minėta aukščiau, dèl kibernetinio saugumo teisinio reguliavimo Lietuvoje apskritai pažymètinas pamatinių teisès normų trūkumas. Vis dėlto pagrindiniai kibernetinio saugumo klausimai turètų būti reglamentuojami įstatymu. Nors Elektroninių ryšių tinklų ir informacijos saugumo įstatymas ir nebuvo priimtas, pamatinès teisès normos kibernetinio saugumo srityje yra Lietuvai kritiškai būtinos. Be kitų svarbių klausimų, 
tokiame ịstatyme turètų būti reglamentuojama ir institucinè kibernetinio saugumo kontrolè bei politikos formavimo aspektai, taip pat interneto paslaugų teikèjų pareigos. Interneto paslaugų teikejų pareigų institutą akcentuoja M. F. Grady ${ }^{35}$, o kibernetinio saugumo strategijoje, neprieštaraujant ịstatymui, galètų būti ịvardijami strateginiai kibernetinio saugumo plètros ir palaikymo aspektai.

\section{Išvados}

1. Viena iš naujausių iniciatyvų - ES kibernetinio saugumo strategija bei direktyvos projektas. Kibernetinio saugumo strategija vertintina kaip išsamus strateginis dokumentas, nuo kurio igyvendinimo priklausys kiekvienos iš ES valstybių kibernetinis saugumas

2. Lietuvoje nèra pamatinių teisès normų, reglamentuojančių kibernetinio saugumo klausimus. Tam tikros holistinio kibernetinio saugumo teisinio reguliavimo iniciatyvos žlugo: buvo parengtas Lietuvos Respublikos elektroninių ryšių tinkle ir informacijos saugumo įstatymo projektas, tačiau šis projektas nebuvo priimtas.

3. Tam tikros teisès normos dèl kibernetinio saugumo numatytos tik Lietuvos Respublikos valstybès informacinių išteklių ịstatyme, tačiau jos reglamentuoja tik valstybės informacinių išteklių saugą bei saugos įgaliotinio institutą, be to, yra fragmentiškos.

4. Lietuvoje patvirtinta kibernetinio saugumo programa vertintina kaip teigiamas žingsnis reglamentuojant kibernetinị saugumą. Tačiau programa turi nemažai trūkumų, yra fragmentiška, nekonkreti, neatitinka kai kurių pagrindinių kibernetinio saugumo tikslų ir uždavinių, todèl tobulintina.

5. Lietuvoje aiškiai jaučiamas pamatinių teisès normų kibernetinio saugumo srityje trūkumas. Be kitų klausimų, tokiame ịstatyme turètų būti aptariami ir institucinès kontrolès bei politikos formavimo kibernetinio saugumo srityje klausimai, taip pat interneto paslaugų teikejjų funkcijos užtikrinant kibernetinį saugumą.

\section{Literatūra}

Cybersecurity Strategy for Germany [interaktyvus]. 2011 [žiūrèta 2013-05-20]. $<$ https://www.bsi.bund.de/SharedDocs/ Downloads/EN/BSI/Publications/ CyberSecurity/Cyber_Security_Strategy_ for_Germany.pdf?_blob=publicationFile>. Communication from the Commission to the Council, the European Parliament, the European Economic and Social Committee and the Committee of the
Regions. Network and Information Security: Proposal for A European Policy Approach. COM/2001/298 [interaktyvus]. Briuselis, 2001 [žiūrèta 2013-05-20]. <http://eur-lex. europa.eu/LexUriServ/site/en/com/2001/ com2001_0298en01.pdfs.

Digital Agenda - Commission consults on a future EU Network and Information Security legislative initiative [interaktyvus]. Briuselis,

35 Grady, M. F.; Parisi, F. 2006. The Law and Economics of Cybersecurity. Cambridge University press, p. 221-256. 
2012 [žiūrèta: 2013-05-20]. < http://europa. eu/rapid/press-release_IP-12-818_en.htm $>$.

Europos Komisija: pranešimas spaudai. ES kibernetinio saugumo planu siekiama apsaugoti atvirą internetą, elektroninę laisvę ir galimybes [interaktyvus]. Briuselis, 2013 [žiūrèta 2013-05-20]. <http://europa.eu/ rapid/press-release_IP-13-94_lt.htm>.

France information systems defence and security strategy [interaktyvus]. 2011 [žiūrèta 2013-05-20]. <http://www.ssi. gouv.fr/IMG/pdf/2011-02-15_Information_ system_defence_and_security_-_France_s_ strategy.pdf $>$.

Grady, M. F.; Parisi, F. 2006. The Law and Economics of Cybersecurity. Cambridge University press.

Jastiuginas, S. 2011. Informacijos saugumo valdymas Lietuvos viešajame sektoriuje. Informacijos mokslai. 57 [interaktyvus]. Vilnius [žiūrèta 2013-05-20]. < http:// www.leidykla.eu/fileadmin/Informacijos mokslai/2011-57/7-25.pdf $>$.

Joint Communication to the European Parliament, the Council, the European Ecomonic and Social Committee and the Committee of Regions „Cybersecurity strategy of the European Union: An Open, Safe and Secure Cyberspace, JOIN/2013/1 final [interaktyvus]. Briuselis, 2013 [žiūrèta 2013-05-20]. <http://ec.europa. eu/information_society/newsroom/cf/dae/ document.cfm?doc_id=1667>.

Komisijos 2009 m. kovo 30 d. komunikatas COM/2009/149 Tarybai, Europos Parlamentui, Europos ekonomikos ir socialinių reikalų komitetui ir Regionų komitetui. „Europos apsauga nuo didelio masto kibernetinių antpuolių ir veiklos sutrukdymo - geresnè parengtis, didesnis saugumas ir atsparumas" [interaktyvus]. Briuselis, 2009 [žiūrèta 2013-05-20]. <http:// eurlex.europa.eu/Notice.do?mode=dbl\&lang $=$ en\&ihmlang=en\&lng $1=$ en, lt\&lng $2=$ bg,cs, da,de,el,en,es, et,fi,fr,hu,it,lt,lv, mt,nl,pl,pt,ro, sk,sl,sv,\&val=493232:cs >.
Komisijos 2012 m. kovo 28 d. komunikatas COM/2012/140 Tarybai ir Europos Parlamentui. Kova su nusikalstamumu skaitmeniniame amžiuje. Europos kovos su elektroniniu nusikalstamumu centro kūrimas [interaktyvus]. Briuselis, 2012 [žiūrèta 2013-05-20]. <http://eur-lex.europa.eu/ LexUriServ/LexUriServ.do?uri=COM:2012 :0140:FIN:LT:PDF>.

Komisijos komunikatas Tarybai, Europos Parlamentui, Europos ekonomikos ir socialinių reikalų komitetui ir Regionų komitetui. Saugios informacinès visuomenès strategija - „Dialogas, partnerystè ir teisių suteikimas“. COM/2006/251 [interaktyvus]. Briuselis, 2006 [žiūrèta 2013-05-20]. <http://eurlex. europa.eu/Notice.do?mode $=$ dbl\&lang $=$ en $\&$ ihmlang=en\&lng $1=$ en, lt\&lng $2=$ cs, da,de,el,e n,es,et,fi,fr,hu,it,lt,lv,nl,pl,pt,sk,sl,sv,\&val=4 27504:cs>.

Lietuvos Respublikos valstybès informacinių išteklių įstatymas Nr. XI1807. Valstybès žinios. 2011, Nr. 163-7739.

Lietuvos Respublikos Vyriausybès 2011 m. birželio 29 d. nutarimas Nr. 796 „Dèl elektroninès informacijos saugos (kibernetinio saugumo) plètros 2011-2019 metais programos patvirtinimo". Valstybès žinios. 2011, Nr. 83-4033; 2011, Nr. 106 (atitaisymas).

Lietuvos Respublikos Vyriausybės nutarimas Nr. 1211 „Dèl Lietuvos Respublikos elektroninių ryšių tinklų ir informacijos saugumo ịstatymo koncepcijos patvirtinimo". Valstybès žinios. 2006, Nr. 134-5081.

Lietuvos Respublikos Vyriausybès nutarimas Nr. 601 „Dèl elektroninès informacijos saugos valstybès institucijų informacinèse sistemose strategijos iki 2008 metu ir jos igyvendinimo priemonių plano patvirtinimo“. Valstybès žinios. 2006, Nr. 70-2575.

Mitrakas, A. 2006. Information Security Law in Europe: Risks Checked. Information \& Communications Technology Law. 15(1).

Proposal for a Directive of European parliament and the Council concerning measures to 
ensure a high common level of network and information security across the Union, $\mathrm{COM} / 2013 / 48$ final [interaktyvus]. Briuselis, 2013 [žiūrèta 2013-05-20]. <http://ec.europa. eu/information_society/newsroom/cf/dae/ document.cfm?doc_id $=1666>$.

Reich, P. C. et al. 2010. Cyber Warfare: A Review of Theories, Law, Policies, Actual Incidents and the Dilemma of Anonymity. European Journal of Law and Technology. 1(2).

Rosenzweig, P. 2013. Cyberwarfare: how conflicts in cyberspace are challenging America and changing the world. Library of Congress Cataloging.

Shoemaker, D.; Conklin, A. 2012. Cybersecurity: the Essential body of knowledge. Course technology.

Štitilis, D.; Klišauskas, V. 2012. Elektroninès informacijos saugos reglamentavimas Lietuvoje ir Rusijoje: lyginamieji aspektai. Socialinès technologijos. 2 (2): 441-455 [interaktyvus]. [žiūrèta 2013-05-20]. $<$ http://www.mruni.eu/lt/mokslo_darbai/st/ archyvas/dwn.php?id=340084>.
Štitilis, D.; Paškauskas, Ž. 2007. Valstybès elektroninès informacijos saugos strategija vienas iš pagrindinių elektroninès informacijos saugos reguliavimo instrumentų: lyginamoji analizè. Jurisprudencija. 2 (92): 37-46.

The UK cyber security strategy: Landscape review [interaktyvus]. 2013 [žiūrèta 201305-20]. <http://www.nao.org.uk/report/ the-uk-cyber-security-strategy-landscapereview/>.

UK cybersecurity strategy.Protecting and promoting the UK in a digital world [interaktyvus]. 2011 [žiūrèta 2013-05-20]. <http://www. carlisle.army.mil/dime/documents/UK\%20 Cyber\%20Security\%20Strategy.pdf $>$.

VU mokslininkas: informacijos saugumo klausimą reikia kelti jau šiandien. Technologijos.lt [interaktyvus]. 2013-0306 [žiūrèta 2013-05-20]. <http://www. technologijos.1t/n/technologijos/it/S-31575/ straipsnis/VU-mokslininkas-informacijossaugumo-klausima-reikia-kelti-jausiandien? $=2 \& \mathrm{p}=1>$.

\section{THE LEGAL REGULATION OF CYBERSECURITY}

\section{Darius Štitilis}

Mykolas Romeris University, Lithuania, stitilis@mruni.eu

Summary. Cybercrime has become a global phenomenon, which is causing more harm to individual citizens, organizations, society and the state. Most countries in the world compare cybercrime with offences such as terrorism and drug trafficking due to its risks and profitability. Cybersecurity is the central category to fight cybercrime in cyberspace. Therefore, the strategic legal regulation of cybersecurity is one of the most relevant problems in EU, including Lithuania. So far cybersecurity legal regulation analysis in scientific literature has been rather limited.

The European Commission, together with the High Representative of the Union for Foreign Affairs and Security Policy, has published a cybersecurity strategy alongside a Commission proposed directive on network and information security (NIS). The cybersecurity strategy - "An Open, Safe and Secure Cyberspace" - represents the EU's comprehensive vision on how best to prevent and respond to cyber disruptions and attacks. The purpose of its is to further European values of freedom and democracy and ensure the digital economy can safely 
grow. Specific actions are aimed at enhancing cyber resilience of information systems, reducing cybercrime and strengthening EU international cyber-security policy and cyber defence.

The main goal of the paper is to analyze and compare the EU cybersecurity strategy and experience of several foreign countries with the strategic legal regulation of cybersecurity in Lithuania.

The article consists of four parts. The first part dealt with the EU cybersecurity strategy. The second part of the article examines the comparative aspect of foreign cybersecurity strategic legal regulation. The third part deals with attempts in Lithuania to draft cybersecurity law and the holistic approach of cybersecurity legal regulation. The fourth part examines Lithuanian cybersecurity strategy and comments on the main probleas related with the strategy.

Several different approaches have been used in the research. The author have used a comparative method to investigate the EU cybersecurity strategy as well a, Lithuanian and foreign situations. The empirical analysis of legal documents was used to determine the legal regulation of the cybersecurity in Lithuania. In addition, Legal acts of the Republic of Lithuania have been analyzed. Having analyzed the official documents, the method allows identifying and describing the relationship between the valid legal regulations accurately. Using literature resources, the author has used the deductive method which allows drawing sufficiently reliable conclusions.

Keywords: cybersecurity, legal regulation. 